\title{
JUKMAS
}

Jurnal Untuk Masyarakat Sehat (JUKMAS)

e-ISSN : 2715-7687

Vol. 5, No. 2 Oktober 2021

P-ISSN : 2715-8748

\section{Pengetahuan, Ketersediaan Data Dan Pengawasan Pimpinan \\ Berhubungan Dengan Keakuratan Laporan Kesehatan Ibu Hamil Dari Puskesmas Ke Dinas Kesehatan Provinsi Dki Jakarta Tahun 2021}

\author{
Mia Haryanto, Sri Siswani \\ Fakultas Ilmu Kesehatan Universitas Respati \\ Indonesia \\ siswnisri@yahoo.co.id
}

\begin{abstract}
Abstrak
Keakuratan pelaksanaan sistem pencatatan dan pelaporan kesehatan Ibu Hamil dari puskesmas ke Dinas Kesehatan Provinsi DKI Jakarta sangat penting dalam upaya menjaga kualitas program kesehatan ibu hamil. Tercatat Angka Kematian Ibu (AKI) dan Angka Kematian Bayi (AKB) di Indonesia, hal ini disebabkan karena salah satu keberhasilan program kesehatan ibu hamil yang baik jika memiliki data dan informasi yang akurat, sehingga pelaku kebijakan kesehatan dapat membuat suatu kebijakan dalam menangani permasalahan tersebut dengan tepat. Tujuan penelitian ini-untuk mengetahui pengetahuan petugas, ketersediaan data dan pengawasan pimpinan berhubungan dengan laporan kesehatan ibu hamil dari puskesmas ke Dinas Kesehatan Provinsi DKI Jakarta.. Jenis penelitian yang digunakan adalah penelitian kuantitatif dengan desain cross sectional, dengan populasi penelitian sebanyak 44 penanggung jawab pelayanan kesehatan ibu hamil di puskesmas kecamatan wilayah kerja Dinas Kesehatan Provinsi DKI Jakarta. Data diperoleh dengan menggunakan kuesioner dan dianalisis dengan menggunakan perangkat lunak statistic untuk uji chi square. Hasil Penelitian menunjukkan bahwa variabel pengetahuan dengan $p$ value $=0,034$ dan variabel ketersediaan data dengan nilai $p$ value 0,041 yang artinya kedua variabel tersebut memiliki hubungan yang bermakna dengan keakuratan laporan kesehatan Ibu Hamil, sedangkan variabel pengawasan pimpinan memiliki $p$ value $=1,00$ yang artinya tidak ada hubungan yang signifikan dengan dengan keakuratan laporan kesehatan Ibu Hamil. Saran dalam penelitian ini adalah Kepala Dinas Kesehatan memberikan akses dan fasilitas dalam peningkatan wawasan secara berkala untuk para petugas kesehatan untuk dapat memahami dengan benar pengisian indikator format laporan kesehatan ibu hamil serta membuat suatu kebijakan terkait kewajiban seluruh FKTP dan FKRTL melampirkan bukti telah melakukan pencatatan dan pelaporan rutin setiap bulannya ke Puskesmas Kecamatan yang ada di wilayah masing-masing kedalam persyaratan untuk mendapatkan rekomendasi perizinan dan perpanjangan izin operasional yang perlu dipenuhi kedalam persyaratan ke PTSP dalam menunjang jejaring cakupan ketersediaan data laporan kesehatan Ibu Hamil.
\end{abstract}
Kata Kunci : Pengetahuan, Ketersediaan Data, Pengawasan Pimpinan, Keakuratan Laporan, Dinas Kesehatan

\section{Abstract}

The accuracy of the implementation of the system of recording and reporting the health of Pregnant Women from puskesmas to the DKI Jakarta Provincial Health Office is very important in an effort to maintain the quality of the health program of pregnant women. The Maternal Mortality Rate (AKI) and Infant Mortality Rate (AKB) in Indonesia are still high; this is due to one of the successes of good maternal health programs if they have accurate data and information, so that health policy actors can make a policy in handling the problem appropriately. The purpose of this research aims to know the http://ejournal.urindo.ac.id/index.php/jukmas

Article History : 
knowledge of officers, the availability of data and supervision of leaders related to the health report of Pregnant Women from puskesmas to the DKI Jakarta Provincial Health Office. The type of research used is quantitative research with cross sectional design, with a research population of 44 persons in charge of maternity health services in the Puskesmas Subdistrict working area of the DKI Jakarta Provincial Health Office. The data was obtained using questionnaires and analyzed using statistics software for chi square tests. The results of the study showed that knowledge variables with a value of $p$ value $=0.034$ and variable availability of data with a value of pvalue 0.041 which means that both variables have a meaningful relationship with the accuracy of the health report of pregnant women, while the lead surveillance variable has $p$ value $=1.00$ which means there is no significant relationship with the accuracy of the health report pregnant women. The advice in this study is that the Head of the Health Office provides access and facilities in improving insights periodically for health officials to be able to properly understand the filling of indicators of the format of the health report of Pregnant Women and make a policy related to the obligations of all FKTP and FKRTL attach evidence to the recording and regular reporting every month to the Puskesmas Kecamatan in their respective regions into the requirements to obtain rekome ndasi licensing and extension of operational permits that need to be fulfilled into the requirements to PTSP in supporting the network of coverage of the availability of data on health reports of Pregnant Women.

Keywords : Knowledge, Data Availability, Leadership Supervision, Report Accuracy, Provincial Health Office 


\section{PENDAHULUAN}

AKI menunjukkan kenaikan dari $62 / 100.000 \mathrm{KH}$ (2013) menjadi 63/100.000 KH (2020) di Provinsi DKI Jakarta. Sedangkan AKB menurun 5/1.000 KH (2013) menjadi 1,6/1.000 KH (tahun 2020). Meskipun AKI dan AKB sudah lebih rendah dari target RPJMN 2019 - 2024 dan SDG's tahun 2030, namun melihat keunggulan Provinsi DKI Jakarta pada akses terhadap fasilitas kesehatan maka AKI dan AKB seharusnya dapat ditekan lebih rendah lagi[1]

Dinas Kesehatan Provinsi DKI Jakarta memiliki 44 puskesmas kecamatan yang terdapat di wilayah kerjanya. Dapat kita ketahui, bahwa kematian Ibu masih terjadi di beberapa wilayah Puskesmas di Pronisi DKI Jakarta. Sebagaimana Program Nasional yaitu Pemantauan Wilayah Setempat (PWS) KIA dan LB3 juga sudah dilakukan secara manual di Puskesmas Kecamatan. Namun masih ditemukan banyak masalah trekait pencatatan dan pelaporannya. Masalah tersebut mencakup masih belum samanya pengetahuan Penanggung Jawab (PJ) Ibu hamil terhadap batasan data yang harus dicatat dan dilaporkan kedalam laporan LB3, kemudian sulitnya jejaring cakupan data dari Fasilitas Kesehatan Tingkat Pertama (FKTP) dan Fasilitas Kesehatan Rujukan Tingkat Lanjut (FKRTL), sehingga membuat pelaporan ke Dinas Kesehatan menjadi tidak lengkap dan tidak akurat. Hal tersebut, pada akhirnya akan mempengaruhi kualitas informasi yang akan diinterpretasikan baik pada tingkat Puskesmas, Kabupaten/Kota, Provinsi, hingga tingkat Nasional [2]
Dinas Kesehatan mengolah Kembali laporan tersebut dan mengirimkan umpan baliknya ke Kementerian Kesehatan. Jika terdapat ketidakakuratan sistem pencatatan dan pelaporan tersebut maka umpan balik yang diberikan menjadi tidak relevan dengan kondisi permasalahan yang ada di Fasilitas Kesehatan di Wilayah Kerja Dinas Kesehatan guna memperbaiki mutu dalam pelayanan kesehatan, serta tidak akan terlihat dan tidak terdokumentasi wujudnya menjadi informasi untuk pengambilan keputusan selanjutnya yang kemudian dijadikan laporan tahunan atau buku profil tahunan DinasKesehatan yang dapat dijadikan sebgai bahan referensi penelitian.

Permasalahan tersebut berdampak pada proses pengolahan serata informasi yang dihasilkan . Keakuratan pelaporan data yang dikirimkan sangat penting dalam kelancaran pengumpulan, penghitungan, dan pengolahan data sehingga dalam penyajian informasi pun mengalami kesesuaian dengan kondisi yang sebenarnya. Keakuratan dan kesesuaian pengolahan data dapat disebabkan karena faktor pengetahuan atau persepsi pemahaman pengisian laporan, ketersediaan data, sertakurangnya pengawasan pimpinan. Pengolahan data yang dilakukan secara manuall dapat mempengaruhi keakuratan data yang dilaporkan dan diolah . [3]

Serta tanangan pembangunan kesehatan menuntut adanya dukungan sumber daya yang cukup serta arah kebijakan dan strategi 
Pembangunan kesehatan yang tepat. Kesulitan pengambil kebijakan dalam mengambil keputusan yang tepat karena keterbatasan atau ketersediaan data dan informasi yang akurat, tepat dan cepat. [4]

Beberapa upaya yang telah dilakukan oleh Dinas Kesehatan Provinsi DKI Jakarta selaku Pembina dan pengawas sistem pencatatan dan pelaporanyang dilakukan oleh Puskesmas yaitu dengan terus diadakannya peningkatan wawasan petugas terkait pengisian buku KIA, pengisian kohort ibu dan pengisian tata cara pencatatan serta pelaporan LB3, melakukan sistem jejaring komunikasi dalam penyampaian data laporan ke Puskesmas Kecamatan dari FKTP dan FKRTL menadapatkan sistem pengampu dari Puskesmas Kecamatan dengan rutin memberikan data laporan setiap bulannya ke Puskesmas Kecamatan. Dan masing-masing puskesmas melakukan rutin rapat koordinasi yang dipimpin oleh masing-masing Kepala Puskesmas dalam rangka pengawasan sistem pencatatan pelaporan puskesmas. Namun, tetap terjadi permasalahan kesenjangan dalam pencatatan pelaporan pelayanan kesehatan ibu hamil dari Puskesmas[5]

Oleh karena permasalahan tersebut, peneliti tertarik untuk melakukan penelusuran terkait pengetahuan petugas, ketersediaan data dan pengawasan pimpinan berhubungan dengan keakuratan laporan kesehatan ibu hamil dari Puskesmas ke Dinas Kesehatan Provinsi DKI Jakarta Tahun 2021.

Penelitian ini guna mendapatkan informasi dan masukan untuk meningkatkan kualitas sistem pencatatan dan pelaporan khususnya Program kesehatan ibu hamil serta dapat dijadikan dasar pembuatan suatu regulasi kebijakan kesehatan terkait pelaksanaan program kesehatan ibu hamil di Dinas Kesehatan Provinsi DKI Jakarta.

\section{METODE}

Penelitian ini menggunakan pendekatan penelitian kuantitatif dengan desain penelitian cross sectional. [6] Tempat penelitian yaitu Seksi Kesehatan Keluarga Bidang Kesehatan Masyarakat Dinas Kesehatan Provinsi DKI
Jakarta, dengan jangka waktu penelitian dari tanggal 19 Maret 2021 sampai dengan 30 Juni 2021. Peneliti menggunakan kuesioner dalam bentuk google form untuk meminimalisir kontak dan menjaga protokol kesehatan di masa pandemic COVID-19 ini. Populasi dalam penelitian ini adalah seluruh penanggung jawab pelayanan kesehatan ibu hamil di Puskesmas Kecamatan wilayah kerja Dinas Kesehatan Provinsi DKI Jakarta sehingga diambil sampel dengan teknik sampling jenuh (Nonprobability Sampling) yaitu keseluruhan jumlah populasi sebanyak 44 penanggung jawab pelayanan kesehatan ibu hamil. Kemudian data hasil penelitian diolah dan dianalisis dengan menggunakan perangkat lunak statistik untuk pengujian chi square (tabulasi silang). [7]

\section{HASIL PENELITIAN}

\section{Karakteristik Responden}

Karakteristik responden yang diteliti meliputi usia, pendidikan dan lama kerja dapat dilihat pada tabel berikut dibawah ini :

Tabel 1

Distribusi Karakteristik Responden Berdasarkan Usia

\begin{tabular}{clcc}
\hline No & $\begin{array}{c}\text { Karakteristik Responden } \\
\text { Berdasarkan Usia }\end{array}$ & $\mathbf{n}$ & $\mathbf{\%}$ \\
\hline 1 & $20-30$ tahun & 3 & 6,8 \\
\hline 2 & $31-40$ tahun & 17 & 38,6 \\
\hline 3 & $41-50$ tahun & 16 & 36,4 \\
\hline 4 & $>50$ tahun & 8 & 18,2 \\
\hline & Total & $\mathbf{4 4}$ & $\mathbf{1 0 0}$ \\
\hline
\end{tabular}

Berdasarkan tabel 1, dapat dilihat bahwa dari 44 responden, responden terbanyak berusia 31 40 tahun yaitu sebanyak 17 orang $(38,6 \%)$.

Tabel 2

Distribusi Karakteristik Responden Berdasarkan Pendidikan

\begin{tabular}{clcc}
\hline No & $\begin{array}{l}\text { Karakteristik Responden } \\
\text { Berdasarkan Pendidikan }\end{array}$ & $\mathbf{n}$ & $\%$ \\
\hline 1 & SMA & 0 & 0 \\
\hline 2 & D3 / Diploma & 30 & 68,2 \\
\hline
\end{tabular}




\begin{tabular}{clcc}
\hline 3 & Sarjana (S1) / Setara & 13 & 29,5 \\
\hline 4 & Pascasarjana (S2) / Setara & 1 & 2,3 \\
\hline Total & $\mathbf{4 4}$ & $\mathbf{1 0 0}$ \\
\hline
\end{tabular}

Berdasarkan tabel 2, dapat dilihat bahwa dari 44 responden, responden terbanyak dari pendidikan D3/Diploma sebanyak 30 orang $(68,2 \%)$

Tabel 3

Distribusi Karakteristik Responden Berdasarkan Lama Kerja

\begin{tabular}{clcc}
\hline No & $\begin{array}{l}\text { Karakteristik Responden } \\
\text { Berdasarkan Lama Kerja }\end{array}$ & $\mathbf{n}$ & $\mathbf{\%}$ \\
\hline 1 & $<3$ tahun & 20 & 45,45 \\
\hline 2 & $3-6$ tahun & 17 & 38,64 \\
\hline 3 & $>6$ tahun & 7 & 15,91 \\
\hline & Total & $\mathbf{4 4}$ & $\mathbf{1 0 0}$ \\
\hline
\end{tabular}

Berdasarkan tabel 3, hasil penelitian pada tabel 5.5 menunjukkan bahwa lama kerja responden yang paling banyak adalah sekitar $<3$ tahun yaitu sebanyak 20 responden (45,5\%).

\section{Analisa Univariat}

Analisis univariat yang diteliti dalam penelitian ini dibagi untuk melihat distribusi frekuensi dari variabel independen dan dependen. Variabel dependen terdiri atas 1 variabel yaitu keakuratan laporan kesehatan ibu hamil. [8]

\begin{tabular}{cccc}
\hline No & $\begin{array}{c}\text { Keakuratan } \\
\text { Laporan }\end{array}$ & $\mathbf{n}$ & $\%$ \\
\hline 1 & Tidak Akurat & 25 & 56,8 \\
\hline 2 & Akurat & 19 & 43,2 \\
\hline
\end{tabular}

Sedangkan Variabel independen terdiri dari 3 variabel yang dibagi menjadi 2 faktor yang meliputi faktor individu yaitu pengetahuan petugas. Faktor organisasi terdiri dari 2 meliputi ketersediaan data dan pengawasan Pimpinan.

\section{Variabel Dependen Keakuratan}

laporan program kesehatan ibu hamil dapat diketahui sebanyak 25 orang $(56,8 \%)$ memiliki kategori keakuratan laporan yang tidak akurat, sedangkan 19 orang $(43,2 \%)$ memiliki kategori keakuratan laporan yang akurat.

\section{Variabel Independen}

\section{1) Pengetahuan}

Tabel 4

Distribusi Kategori Keakuratan Laporan Kesehatan Ibu Hamil di Puskesmas Kecamatan

Berdasarkan tabel 4, hasil perhitungan total skor secara keseluruhan mengenai keakuratan

Tabel 5

Distribusi Kategori Pengetahuan Responden

\begin{tabular}{cccc}
\hline No & Pengetahuan & $\mathbf{n}$ & $\%$ \\
\hline 1 & Kurang Baik & 24 & 54,5 \\
\hline 2 & Baik & 20 & 45,5 \\
\hline
\end{tabular}

Berdasarkan tabel 5, hasil perhitungan total skor secara keseluruhan mengenai pengetahuan tentang pengisian format LB3 dalam program kesehatan ibu hamil dapat diketahui sebanyak 24 orang $(54,5 \%)$ memiliki kategori pengetahuan kurang baik, sedangkan 20 orang $(45,5 \%)$ memiliki pengetahuan baik.

\section{2) Ketersediaan Data}

Tabel 6

Distribusi Kategori Ketersediaan Data di Puskesmas Kecamatan

\begin{tabular}{cccc}
\hline No & Ketersediaan Data & $\mathbf{n}$ & $\%$ \\
\hline 1 & Kurang Baik & 26 & 59,1 \\
\hline 2 & Baik & 18 & 40,9 \\
\hline
\end{tabular}

Berdasarkan tabel 6, hasil perhitungan total skor secara keseluruhan mengenai ketersediaan data untuk mendukung pengisian pengisian format LB3 dalam program kesehatan ibu hamil dapat diketahui sebanyak 26 orang $(59,1 \%)$ memiliki kategori ketersediaan yang kurang baik, sedangkan 18 orang $(40,9 \%)$ memiliki ketersediaan data yang baik.

\section{3) Pengawasan Pimpinan}


Tabel 7

Distribusi Kategori Ketersediaan Data di Puskesmas Kecamatan

\begin{tabular}{cccc}
\hline No & $\begin{array}{l}\text { Pengawasan } \\
\text { Pimpinan }\end{array}$ & n & \% \\
\hline 1 & Kurang Baik & 29 & 65,9 \\
\hline 2 & Baik & 15 & 34,1 \\
\hline
\end{tabular}

Berdasarkan tabel 7, hasil perhitungan total skor secara keseluruhan mengenai pengawasan pimpinan untuk memantau dan evaluasi pengisian format LB3 dalam program kesehatan ibu hamil dapat diketahui sebanyak 29 orang $(65,9 \%)$ memiliki kategori pengawasan pimpinan yang kurang baik, sedangkan 15 orang $(34,1 \%)$ mendapatkan pengawasan pimpinan yang baik.

\section{Analisa Bivariat}

Analisis bivariat yang digunakan untuk mengidentifikasi hubungan variabel independen (pengetahuan, ketersediaan data dan pengawasan pimpinan) dengan variabel dependen yaitu keakuratan laporan kesehatan Ibu Hamil dari Puskesmas ke Dinas Kesehatan Provinsi DKI Jakarta. [9]

1. Hubungan Antara Pengetahuan Dengan Keakuratan Laporan dari Puskesmas ke Dinas Kesehatan Provinsi DKI Jakarta

\section{Tabel 8}

Distribusi Hubungan antara Pengetahuan dengan Keakuratan Laporan Kesehatan Ibu Hamil

\begin{tabular}{|c|c|c|c|c|c|c|c|c|}
\hline \multirow{3}{*}{$\begin{array}{c}\text { Pengetah } \\
\text { uan }\end{array}$} & \multicolumn{4}{|c|}{ Keakuratan } & \multirow{2}{*}{\multicolumn{2}{|c|}{ Total }} & \multirow{3}{*}{$\begin{array}{c}P \\
\text { Val } \\
\text { ue }\end{array}$} & \multirow{3}{*}{$\begin{array}{c}\text { OR } \\
(95 \% \\
\mathrm{Cl})\end{array}$} \\
\hline & \multicolumn{2}{|c|}{$\begin{array}{c}\text { Tidak } \\
\text { Akurat }\end{array}$} & \multicolumn{2}{|c|}{ Akurat } & & & & \\
\hline & $\mathrm{n}$ & $\%$ & $\mathrm{n}$ & $\%$ & $\mathrm{n}$ & $\%$ & & \\
\hline $\begin{array}{c}\text { Kurang } \\
\text { Baik }\end{array}$ & $\begin{array}{l}1 \\
3\end{array}$ & $\begin{array}{c}54, \\
2\end{array}$ & $\begin{array}{l}1 \\
1\end{array}$ & $\begin{array}{c}45, \\
8\end{array}$ & $\begin{array}{l}2 \\
4\end{array}$ & $\begin{array}{c}10 \\
0\end{array}$ & \multirow{3}{*}{$\begin{array}{l}0,0 \\
34\end{array}$} & \multirow{3}{*}{$\begin{array}{c}7,88 \\
(2,37 \\
- \\
12,62 \\
1)\end{array}$} \\
\hline Baik & 8 & 40 & $\begin{array}{l}1 \\
2\end{array}$ & 60 & $\begin{array}{l}2 \\
0\end{array}$ & $\begin{array}{c}10 \\
0\end{array}$ & & \\
\hline Jumlah & $\begin{array}{l}2 \\
1\end{array}$ & $\begin{array}{l}47, \\
72\end{array}$ & $\begin{array}{l}2 \\
3\end{array}$ & $\begin{array}{l}52, \\
27\end{array}$ & $\begin{array}{l}4 \\
4\end{array}$ & $\begin{array}{c}10 \\
0\end{array}$ & & \\
\hline
\end{tabular}

Berdasarkan tabel 8, hasil tabulasi silang antara variabel pengetahuan dengan variabel keakuratan laporan menunjukkan dari 24 responden yang pengetahuannya kurang baik, sebanyak 13 responden $(54,2 \%)$ laporannya tidak akurat dan 11 responden $(45,8 \%)$ yang akurat. Sedangkan, dari 20 responden yang pengetahuannya baik, sebanyak 8 responden (40\%) laporanya tidak akurat dan 12 responden (60\%) yang akurat.

Pada pengujian bivariat menggunakan analisa chi square, menunjukkan hasil dari P.value sebesar 0,034, yang artinya P.value $<0,05$ sehingga ada hubungan yang bermakna antara pengetahuan penanggung jawab laporan kesehatan ibu hamil dengan keakuratan laporan.

Hasil analisis diperoleh pula nilai $O R=7,88$ yang artinya petugas penanggung jawab laporan kesehatan ibu hamil yang memiliki pengetahuan yang baik mempunyai peluang 7,88 kali untuk membuat laporan kesehatan ibu hamil yang akurat dibandingkan dengan petugas yang pengetahuannya kurang baik.

\section{Hubungan Antara Ketersediaan Data Dengan Keakuratan Laporan dari Puskesmas ke Dinas Kesehatan Provinsi DKI Jakarta}

Tabel 9

Distribusi Hubungan antara Ketersediaan Data dengan Keakuratan Laporan Kesehatan Ibu Hamil

\begin{tabular}{|c|c|c|c|c|c|c|c|c|}
\hline \multirow{3}{*}{$\begin{array}{l}\text { Ketersedi } \\
\text { aan Data }\end{array}$} & \multicolumn{4}{|c|}{ Keakuratan } & \multirow{2}{*}{\multicolumn{2}{|c|}{ Total }} & \multirow{3}{*}{$\begin{array}{c}P \\
\text { Val } \\
\text { ue }\end{array}$} & \multirow{3}{*}{$\begin{array}{c}\text { OR } \\
(95 \% \\
\mathrm{Cl})\end{array}$} \\
\hline & \multicolumn{2}{|c|}{$\begin{array}{c}\text { Tidak } \\
\text { Akurat }\end{array}$} & \multicolumn{2}{|c|}{ Akurat } & & & & \\
\hline & $\mathrm{n}$ & $\%$ & $\mathrm{n}$ & $\%$ & $\mathrm{n}$ & $\%$ & & \\
\hline Kurang & 1 & 69 , & 8 & 30 & 2 & 10 & & \\
\hline Baik & 8 & 2 & 0 & 8 & 6 & 0 & & 3,536 \\
\hline Baik & 7 & 38 , & 1 & 61, & 1 & 10 & 0,04 & 1 - \\
\hline & & 9 & 1 & 1 & 8 & 0 & 1 & 12. 48 \\
\hline lumlah & 2 & 56 , & 1 & 43, & 4 & 10 & & (1), \\
\hline Juminati & 5 & 8 & 9 & 2 & 4 & 0 & & \\
\hline
\end{tabular}

Berdasarkan tabel 9, hasil tabulasi silang antara variabel ketersediaan data dengan variabel keakuratan laporan menunjukkan dari 26 responden yang ketersediaan data kurang baik, sebanyak 18 responden (69,2\%) laporannya tidak akurat dan 8 responden $(30,8 \%)$ yang akurat. Sedangkan, dari 18 responden yang ketersediaan datanya baik, sebanyak 7 responden $(38,9 \%)$ laporanya tidak akurat dan 11 responden $(61,1 \%)$ yang akurat.

Pengujian bivariat menggunakan analisa chi square, menunjukkan hasil dari P.value 
sebesar 0,041 $<0,05$ artinya ada hubungan yang bermakna antara ketersediaan data dengan keakuratan laporan.

Hasil analisis diperoleh pula nilai $O R=3,536$ yang artinya puskesmas yang memiliki ketersediaan data untuk mendukung pembuatan laporan kesehatan ibu hamil yang baik mempunyai peluang 3,536 kali untuk membuat laporan kesehatan ibu hamil yang akurat dibandingkan dengan puskesmas yang ketersediaan datanya kurang baik.

\section{Hubungan Antara Pengawas Pimpinan Dengan Keakuratan Laporan dari Puskesmas ke Dinas Kesehatan Provinsi DKI Jakarta}

Tabel 10

Distribusi Hubungan antara Pengawasan Pimpinan dengan Keakuratan Laporan Kesehatan Ibu Hamil

\begin{tabular}{|c|c|c|c|c|c|c|c|c|}
\hline \multirow{3}{*}{$\begin{array}{l}\text { Pengawa } \\
\text { san } \\
\text { Pimpinan }\end{array}$} & \multicolumn{4}{|c|}{ Keakuratan } & \multirow{2}{*}{\multicolumn{2}{|c|}{ Total }} & \multirow{3}{*}{$\begin{array}{l}\text { P } \\
\text { Val } \\
\text { ue }\end{array}$} & \multirow{3}{*}{$\begin{array}{c}\text { OR } \\
(95 \\
\% \\
\text { Cl) }\end{array}$} \\
\hline & \multicolumn{2}{|c|}{$\begin{array}{c}\text { Tidak } \\
\text { Akurat }\end{array}$} & \multicolumn{2}{|c|}{ Akurat } & & & & \\
\hline & $\mathrm{n}$ & $\%$ & $\mathrm{n}$ & $\%$ & $\mathrm{n}$ & $\%$ & & \\
\hline $\begin{array}{c}\text { Kurang } \\
\text { Baik }\end{array}$ & 1 & $\begin{array}{c}55, \\
2\end{array}$ & $\begin{array}{l}1 \\
3\end{array}$ & $\begin{array}{c}44, \\
8\end{array}$ & 2 & $\begin{array}{c}10 \\
0\end{array}$ & & $\begin{array}{c}0,82 \\
1\end{array}$ \\
\hline Baik & 9 & 60 & 6 & 40 & $\begin{array}{l}1 \\
5\end{array}$ & $\begin{array}{c}10 \\
0\end{array}$ & 1 & $\begin{array}{l}(0,2 \\
31-\end{array}$ \\
\hline Jumlah & $\begin{array}{l}2 \\
5\end{array}$ & $\begin{array}{c}56, \\
8\end{array}$ & $\begin{array}{l}1 \\
9\end{array}$ & $\begin{array}{c}43, \\
2\end{array}$ & $\begin{array}{l}4 \\
4\end{array}$ & $\begin{array}{c}10 \\
0\end{array}$ & & $\begin{array}{c}2,91 \\
0)\end{array}$ \\
\hline
\end{tabular}

Berdasarkan tabel 10, hasil tabulasi silang antara variabel pengawasan pimpinan dengan variabel keakuratan laporan menunjukkan dari 29 responden yang pengawasan pimpinanya kurang baik, sebanyak 16 responden $(55,2 \%)$ laporannya tidak akurat dan 13 responden $(44,8 \%)$ yang akurat. Sedangkan, dari 15 responden yang pengawasan pimpinannya baik, sebanyak 9 responden (60\%) laporanya tidak akurat dan 6 responden (40\%) yang akurat.

Pada pengujian bivariat menggunakan analisa chi square, menunjukkan hasil dari P.value sebesar 1 , yang artinya P.value $>0,05$ sehingga tidak adanya hubungan yang bermakna antara pengawasan pimpinan dengan keakuratan laporan.

\section{PEMBAHASAN}

1. Keakuratan Laporan Dalam Pelaksanaan Program Kesehatan Ibu Hamil dari Puskesmas ke Dinas Kesehatan Provinsi DKI Jakarta

Hasil penelitian keakuratan laporan dalam pelaksanaan program kesehatan ibu hamil dari puskesmas kecamatan ke Dinas Kesehatan Provinsi DKI Jakarta menggunakan uji chi square menunjukkan bahwa laporan tidak akurat, karena dari 44 penanggung jawab laporan terdapat 25 yang tidak akurat dan 19 yang akurat.

Sebagian besar petugas telah mengisi lengkap seluruh indikator format laporan LB3 sebanyak 34 responden (77,3\%), dan sisanya ada 10 responden $(22,7 \%)$ yang tidak mengisi lengkap seluruh indikator format LB3. Tetapi petugas yang mengisi indikator format laporan LB3 tidak mendapatkan seluruh data cakupan kesehatan ibu hamil dari Fasilitas Kesehatan Tingkat Pertama (FKTP) dan Fasilitas Kesehatan Rujukan Tingkat Lanjut (FKRTL) yang ada diwilayah kerja Puskesmas Kecamatan, sehingga data yang ditampilkan tidak menjadi gambaran hasil yang sebenarnya dari suatu capaian wilayah kerja puskesmas kecamatan tersebut sebanyak 35 responden (79,5\%), hanya 9 responden $(20,5 \%)$ yang melaporakan seluruh data cakupan kesehatan ibu hamil dari seluruh FKTP dan FKRTL yang ada di wilayah puskesmas kecamatannya. Ketidakadaan data tersebut didukung pula dengan petugas yang tidak mendapatkan informasi hasil skrinning yang tidak sesuai dari hasil anamnesa pasien ibu hamil sebanyak 31 responden $70,5 \%$ ) dan hanya 13 responden $(29,5 \%)$ yang mengisi informasi hasil skrinning yang sesuai dari anamnesa pasien, sehingga petugas memungkinkan memasukkan data yang tidak tepat kedalam laporan kesehatan ibu hamil tiap bulannya.

Petugas juga telah mengisi lengkap seluruh indikator format laporan LB3 sesuai definisi operasionalnya sebanyak 38 responden $(86,4 \%)$ dan hanya 6 responden $(13,6 \%)$ yang merasa tidak mengisi indikator format laporan sesuai definisi operasional, namun laporan yang di isi belum terintegrasi kedalam suatu sistem satu data yang dapat menyebabkan kemungkinan data yang terinput berulang (double data) sebanyak 37 responden (84,1\%). Berarti hanya 7 responden $(15,9 \%)$ yang membuat laporan 
terintegrasi untuk wilayah kerjanya. Double data tersebut dapat terjadi dikarenakan satu data pasien dapat terinput ulang kedalam kohort posyandu, kohort puskesmas kelurahan ataupun puskesmas kecamatan, register Bidan Praktik Swasta dan register pencatatan di Rumah Sakit yang melakukan penginputan dalam sistem yang berbeda yang kemudian terlaporkan berulang ke Puskesmas Kecamatan. Dengan distribusi indikator keakuratan laporan yang paling banyak tidak dilakukan petugas yaitu terkait petugas yang melaporkan seluruh data cakupan kesehatan ibu hamil dari seluruh FKTP dan FKRTL yang ada diwilayah kerja Puskesmas Kecamatan kedalam laporan kesehatan ibu hamil.

Laporan kesehatan ibu hamil dari puskesmas ke Dinas Kesehatan Provinsi DKI Jakarta masih mengalami ketidakakuratan data. Hal ini terkait masalah didalam pengelolaan sumber daya, baik sumber daya manusia dari mulai petugas itu sendiri hingga pimpinannya dan sumber daya dalam mendukung suatu pencatatan pelaporan dalam hal penelitian ini termasuk ketersediaan data. Aspek-aspek tersebut harus diperhatikan dengan serius. Perhatian yang penuh terhadap permasalahan sumber daya ini sebaiknya tidak dilakukan sendiri-sendiri namun melibatkan aspek lainnya yang diperkirakan dapat mempengaruhi keakuratan laporan dari pencatatan dan pelaporan tersebut. [10]

\section{Hubungan Pengetahuan Petugas dengan Keakuratan Laporan Kesehatan Ibu Hamil dari Puskesmas ke Dinas Kesehatan Provinsi DKI Jakarta}

Hasil analisis bivariat dengan menggunakan uji chi square, adanya hubungan yang bermakna atau signifikan antara pengetahuan petugas kesehatan ibu hamil terhadap keakuratan laporan kesehatan ibu hamil dari Puskesmas ke Dinas Kesehatan Provinsi DKI Jakarta.

Menurut hasil penelitian tersebut bahwa responden yang menjawab pertanyaan yang ada dikuesioner dengan benar yang berarti responden yang memiliki pengetahuan yang baik sehingga membuat laporan menjadi akurat sebaliknya responden yang menjawab tidak benar dengan tingkat pengetahuan kurang baik membuat laporan menjadi tidak akurat. Tingkat pengetahuan menunjukkan mayoritas dalam kategori kurang baik Dengandistribusi jawaban kuesioner yang paling banyak tidak dipahami oleh responden adalah terkait pertanyaan tentang K1 Murni, kunjungan ibu hamil K4 dan pemberian imunisasi $\pi T 2+$.

Hasil tabulasi silang tingkat pengetahuan dengan keakuratan laporan yang hasilnya menunjukkan mayoritas pengetahuan responden kurang baik sehingga membuat laporan menjadi tidak akurat. Ini sangat berbanding lurus dan sangat berpengaruh antara pengetahuan dengan keakuratan laporan.

Dengan pengetahuan petugas yang baik maka petugas penanggung jawab laporan kesehatan ibu hamil dapat diharapkan mengisi seluruh indikator format laporan kesehatan ibu hamil sesuai definisi operasional yang tepat. Karena apabila ada kesalahan pemahaman indikator dalam pengisian akan membuat data yang terinput menjadi tidak sesuai pula. Sehingga rekapitulasi data masing-masing indikator laporan yang di hasilkan menjadi tidak akurat tiap bulannya antar Puskesmas yang satu dengan yang lainnya pun dapat berbeda penginputannya. Hal ini menyebabkan data yang terkumpul di Dinas Kesehatan Provinsi DKI Jakarta akan sangat berpengaruh tidak akurat. Pengetahuan tentang tugas merupakan pedoman yang penting bagi petugas untuk membuat suatu laporan yang akurat. [11]

Pengetahuan yang baik tentang tugasnya akan meningkatkan kualitas pekerjaannya. Bagi seorang petugas, peningkatan pengetahuan dapat diperoleh melalui pendidikan dan pelatihan. Disamping itu dengan meningatkatnya ilmu pengetahuan dan teknologi dapat menjadikan media dalam menambah pengetahuan tentang ilmu-ilmu yang berkembang di dunia luar sehingga petugas dapat menyelesaikan tugas-tugasnya dan dapat 
berinovasi melalui ilmu yang dimiliki serta dapat menyelesaikan masalah melalui pemikiran dalam setiap pemecahan masalah.

Dengan demikian pengetahuan petugas sangat berpengaruh dengan keakuratan laporan kesehatan ibu hamil dari Puskesmas ke Dinas Kesehatan Provinsi DKI Jakarta, dan petugas harus banyak memahami tentang program kesehatan ibu hamil dan bagaimana cara membuat laporang yang akurat.

\section{Hubungan Ketersediaan Data dengan Keakuratan Laporan Kesehatan Ibu Hamil dari Puskesmas ke Dinas Kesehatan Provinsi DKI Jakarta}

Hasil analisis bivariat dengan menggunakan uji chi square, variabel ketersediaan data didapatkan P.value $=0,041(p<0,05)$. Dengan demikian dapat disimpulkan bahwa adanya pengaruh yang bermakna atau signifikan antara ketersediaan data dalam mendukung laporan kesehatan ibu hamil terhadap keakuratan laporan kesehatan ibu hamil dari Puskesmas ke Dinas Kesehatan Provinsi DKI Jakarta.

Menurut hasil penelitian tersebut bahwa responden yang menjawab setuju sesuai pernyataan yang ada dikuesioner terkait ketersediaan data berarti responden yang memiliki ketersediaan data yang baik sehingga membuat laporan menjadi akurat sebaliknya responden yang menjawab tidak setuju dengan ketersediaan data kurang baik membuat laporan menjadi tidak akurat. Kategori ketersediaan data menunjukkan bahwa sebanyak 26 responden $(59,1 \%)$ yang memberikan pernyataan kategori ketersediaan data di Puskesmasnya kurang baik dan sebanyak 18 responden (40,9\%) yang memiliki ketersediaan data di Puskesmasnya baik.

Dan dapat diketahui hasil tabulasi silang kategori ketersediaan data dengan keakuratan laporan yang hasilnya menunjukkan dari 26 responden yang ketersediaan datanya kurang baik, ada 18 responden yang laporannya tidak akurat dan 8 responden yang laporannya akurat. Sedangkan dari 18 responden yang ketersediaan datanya baik, ada 11 yang laporannya akurat dan 7 laporannya tidak akurat. Ini juga sangat berbanding lurus dan sangat berpengaruh antara ketersediaan data dengan keakuratan laporan kesehatan ibu hamil.

Permasalahan yang hampir seluruh responden jawab adalah tidak tersedianya data yang lengkap dari pelayanan kesehatan ibu hamil di Bidan Praktik Swasta sebanyak 23 responden $(52,3 \%)$, tidak tersedianya data yang lengkap dari pelayanan kesehatan ibu hamil di Klinik Swasta sebanyak 29 responden (65,9\%), tidak tersedianya data yang lengkap dari pelayanan kesehatan ibu hamil di Posyandu sebanyak 31 responden $(70,5 \%)$ dan tidak tersedianya data yang lengkap dari pelayanan kesehatan ibu hamil di Rumah Sakit sebanyak 35 responden $(79,5 \%)$. Hanya 3 (tiga) fasilitas kesehatan yang dinilai Puskesmas Kecamatan mendapatkan data yang lengkap hasil pelayanan kesehatan ibu hamilnya yaitu dari Puskesmas Kecamatan itu sendiri, Puskesmas Kelurahan dan Posyandu. Dengan distribusi jawaban responden terkait ketersediaan data yang paling tidak tersedia lengkap cakupannya berasal dari fasilitas pelayanan kesehatan ibu hamil dari Rumah Sakit, Posyandu serta Klinik Swasta dan Bidan Praktik Swasta.

Hal itu terjadi dikarenakan masih kurangnya jejaring komunikasi antara pihak Puskesmas Kecamatan selaku pengampu wilayah kerja dengan Fasilitas Kesehatan lain yang ada disekitar Puskesmas Kecamatan tersebut, sehingga koordinasi pengiriman laporan menjadi tidak terorganisir dengan baik.

Ketersediaan data menjadi hal yang sangat penting bagi petugas untuk dapat memasukkan data kedalam masing-masing indikator format laporan LB3 dari berbagai Fasilitas Kesehatan Tingkat Pertama (FKTP) serta Fasilitas Kesehtaan Rujukan Tingkat Lanjut (FKRTL) baik dari Puskesmas Kecamatan itu sendiri, Puskesmas Kelurahan, Bidan Praktek Swasta, Klinik Swasta, Posyandu dan Rumah Sakit. [12]

Tidak hanya ketersediaan data yang lengkap dan sesuai cakupan namun diperlukan ketersediaan data yang rutin dilaporkan oleh seluruh fasilitas kesehatan tersebut. Dengan ketersediaan data yang rutin dan lengkap yang melingkupi seluruh FKTP dan FKRTL menjadikan laporan yang dibuat menjadi akurat sesuai dengan keadaan yang 
sebenarnya mewakili keadaaan wilayah kerja Puskesmas Kecamatannya masing-masing. [13]

Dengan hasil yang sesuai cakupan akan menggambarkan permasalahan yang harus segera diselesaikan oleh pihak puskesmas maupun Dinas Kesehatan Provinsi sebagai regulator peembuat kebijakan untuk mengatasi permasalahan yang ada sehingga tepat sasaran. Namun sebaliknya jika laporan yang dikirimkan tidak berdasarkan data yang sesungguhkan menyebabkan kesulitan dalam menyelesaikan permasalahan dari tingkat bawah di FKTP hingga tingkat FKRTL. Dengan demikian fungsi ketersediaan data yang baik sangat berpengaruh besar terhadap keakuratan laporan kesehatan ibu hamil dari Puskesmas ke Dinas Kesehatan Provinsi DKI Jakarta.

\section{Hubungan Pengawasan Pimpinan dengan Keakuratan Laporan Kesehatan Ibu Hamil dari Puskesmas ke Dinas Kesehatan Provinsi DKI Jakarta}

Hasil analisis bivariat dengan menggunakan uji chi square, variabel ketersediaan data didapatkan P.value $=1,000(p>0,05)$. Dengan demikian dapat disimpulkan bahwa tidak adanya pengaruh yang bermakna atau signifikan antara pengawasan pimpinan terhadap keakuratan laporan kesehatan ibu hamil dari Puskesmas ke Dinas Kesehatan Provinsi DKI Jakarta.

Menurut hasil penelitian tersebut bahwa responden yang menjawab setuju sesuai pernyataan yang ada dikuesioner terkait pengawasan pimpinan berarti responden yang memiliki pengawasan pimpinan yang baik sehingga membuat laporan menjadi akurat sebaliknya responden yang menjawab tidak setuju dengan pengawasan pimpinan yang kurang baik membuat laporan menjadi tidak akurat. Kategori pengawasan pimpinan menunjukkan bahwa sebanyak 29 responden $(65,9 \%)$ yang memberikan pernyataan kategori pengawasan pimpinan di Puskesmasnya kurang baik dan sebanyak 15 responden (34,1\%) yang pengawasan pimpinan di Puskesmasnya baik.

Dan dapat diketahui hasil tabulasi silang kategori pengawasan pimpinan dengan keakuratan laporan yang hasilnya menunjukkan dari 29 responden yang pengawasan pimpinannya kurang baik, ada 16 responden yang laporannya tidak akurat dan 13 responden yang laporannya akurat. Sedangkan dari 15 responden yang pengawasan pimpinannya baik, ada 6 yang laporannya akurat dan 9 laporannya tidak akurat. Ini berarti tidak berbanding lurus dan tidak signifikan berpengaruh antara pengawasan pimpinan dengan keakuratan laporan kesehatan ibu hamil.

Walau hasil tabulasi silang tersebut dianggap tidak bermakna atau tidak signifikan berpengaruh namun berdasarkan hasil distribusi frekuensi, bahwa sebenarnya dapat kita lihat antara pengawasan yang kurang baik maka hasil laporannya pun akan menjadi tidak akurat. Karena pemimpin yang baik akan memberi kontribusi yang cukup besar terhadap kinerja para petugas khususnya dalam pelaksanaan pencatatan pelaporan yang baik dan akurat. Serta pengawasan pimpinan dapat menciptakan suasana kondusif bagi petugas untuk mengikuti arahan yang benar jika petugas menghadapi kendala dalam proses pencatatan pelaporan baik peningkatan wawasan petugas, proses pengumpulan data, jejaring fasilitas kesehatan, hingga capaian cakupan yang masih rendah. Semua itu dapat teratasi jika adanya kontribusi pengawasan pimpinan yang secara berkala dan berkelanjutan. [14]

Beberapa petugas mengakui bahwa mereka masih kurang mampu melaksanakan pencatatan pelaporan dengan baik tanpa pengawasan pimpinannya. Masih banyaknya Kepala Puskesmas yang tidak memberikan solusi langsung dalam mengatasi kendala pencatatan pelaporan, Kepala Puskesmas tidak melakukan pengawasan terhadap ketepatan waktu dan keakuratan laporan, Kepala Puskesmas tidak selalu membaca hasil kertas kerja laporan sebelum dikirimkan ke Dinas Kesehatan, dan Kepala Puskesmas tidak memberikan pujian ketika petugas melakukan pekerjaannya dengan baik, tetapi sebaliknya banyak yang mengakui mendapat teguran saat tidak menjalankan tugasnya dengan baik oleh pimpinannya. Dengan distribusi jawaban responden terkait pengawasan pimpinan yang paling banyak tidak dilakukan oleh pimpinan puskesmas adalah membaca dan mengevaluasi hasil kertas kerja laporan kesehatan ibu hamil sebelum dikirimkan ke Dinas Kesehatan Provinsi. [15] 
Kurangnya pengawasan pimpinan dalam hal membaca dan mengevaluasi kertas kerja laporan dikarenakan adanya sistem pelaporan yang digunakan Puskesmas Kecamatan ke Dinas Kesehatan Provinsi DKI Jakarta menggunakan Google Spreadsheet yang tidak mengharuskan pimpinan menandatangani laporan hardcopy, sehingga proses evaluasi lembar kertas kerja tersebut menjadi terabaikan. Serta dengan kurangnya pengawasan pimpinan yang aktif, peneliti berpendapat memungkinkan terjadinya ketidaksesuaian terkait beban kerja yang dihadapi oleh petugas, sehingga memungkinkan petugas membuat laporan kesehatan ibu hamil menjadi tidak akurat. [16]

Dengan demikian walaupun hasil uji statistik yang dilakukan tidak memiliki hubungan terkait pengawasan pimpinan dengan kekauratan laporan namun dalam kenyataannya proses pencatatan pelaporan di Puskesmas Kecamatan tetap membutuhkan peran pengawasan pimpinan dalam menjaga keakuratan laporan kesehatan ibu hamil dari Puskesmas ke Dinas Kesehatan Provinsi DKI Jakarta.

\section{KESIMPULAN}

Berdasarkan hasil penelitian tentang pengetahuan petugas, ketersediaan data dan pengawasan pimpinan berhubungan dengan keakuratan laporan kesehatan ibu hamil dari puskesmas ke Dinas Kesehatan Provinsi DKI Jakarta yang telah dilakukan, maka dapat disimpulkan sebagai berikut:

a. Adanya hubungan yang bermakna atau signifikan antara pengetahuan petugas penanggung jawab laporan kesehatan ibu hamil Puskesmas Kecamatan dengan keakuratan laporan kesehatan ibu hamil yang dikirim ke Dinas Kesehatan Provinsi DKI Jakarta;

b. Adanya hubungan yang bermakna atau signifikan antara ketersediaan data untuk dasar pembuatan laporan kesehatan ibu hamil Puskesmas Kecamatan dengan keakuratan laporan kesehatan ibu hamil yang dikirim ke Dinas Kesehatan Provinsi DKI Jakarta;

c. Tidak adanya hubungan yang bermakna atau signifikan secara analisa statistik antara pengawasan pimpinan Puskesmas Kecamatan dengan keakuratan laporan kesehatan ibu hamil, namun secara analisa deskriptif atau gambaran hasil jawaban kuesioner menunjukkan hubungan yang berbanding lurus antara pengawasan pimpinan Puskesmas Kecamatan dengan keakuratan laporan kesehatan ibu hamil yang dikirim ke Dinas Kesehatan Provinsi DKI Jakarta.

\section{SARAN}

Berdasarkan hasil penelitian yang telah dilakukan serta kesimpulan yang telah dibuat, maka penulis mengajukan beberapa saran sebagai berikut :

a. Kepada Kepala Dinas Kesehatan Provinsi DKI Jakarta agar mengadakan peningkatan wawasan pemahaman terkait program kesehatan ibu hamil dengan sasaran tidak hanya untuk petugas puskesmas, namun ke petugas kesehatan ibu hamil yang ada di FKTP dan FKRTL di wilayah kerja Dinas Kesehatan DKI Jakarta;

b. Kepada Kepala Dinas Kesehatan untuk membuat suatu kebijakan terkait kewajiban seluruh FKTP dan FKRTL melampirkan bukti telah melakukan pencatatan dan pelaporan rutin setiap bulannya ke Puskesmas Kecamatan yang ada di wilayah masing-masing kedalam persyaratan untuk mendapatkan rekomendasi perizinan dan perpanjangan izin operasional yang perlu dipenuhi kedalam persyaratan ke PTSP;

c. Kepada Kepala Puskesmas untuk melakukan pengawasan dalam menilai dan mengevaluasi pelaksanaan kegiatan program kesehatan ibu hamil khususnya dalam memantau pencatatan dan pelaporannya, sehingga tidak lagi membuat laporan yang tidak akurat;

d. Kepada petugas puskesmas untuk meningkatkan kinerja yang baik dalam hal pembuatan laporan kesehatan ibu hamil, sehingga menghasilkan laporan yang akurat dan dapat dipertanggung jawabkan;

e. Kepada peneliti lain agar melakukan penelitian yang sejenis dengan 


\section{DAFTAR PUSTAKA}

1. Kementrian Kesehatan RI (2020) 'Indikator Program Kesehatan Masyarakat Dalam RPJMN Dan Renstra Kementrian Kesehatan Tahun 2020 2024', Kemenkes RI.

2. Dinas Kesehatan Provinsi DKI Jakarta, S.K.K (2020). 'Laporan Evaluasi Program Kesehatan Ibu dan Anak'.

3. Dinas Kesehatan Provinsi DKI Jakarta (2020). Laporan LB3 Dinas Kesehatan Provinsi DKI Jakarta Tahun 2020.

4. Kementrian Kesehatan Republik Indonesia (2015) Buku Ajar Kesehatan Ibu Dan Anak, Departemen Kesehatan Republik Indonesia.

5. Dinas Kesehatan Provinsi DKI Jakarta (2019) Juknis Fasilitas Kesehatan Mampu Tatalaksana Kegawatdaruratan Maternal Neonatal, Dinas Kesehatan Provinsi DKI Jakarta.

6. Sugiyono (2008) Metode Penelitian Administrasi, Edisi 2008. Bandung: Alfabeta.

7. Sugiyono (2009) Metode Penelitian Kuantitatif Kualitatif dan R\&D. cetakan kedelapan. Bandung : Alfabeta.

8. Budiarto, Eko (2001) Biostatistik untuk Kedokteran dan Kesehatan Masyarakat. Jakarta : Penerbit Buku Kedokteran EGC.

9. Suryani (2015) Metode Riset Kuantitatif. Jakarta : Prenadamedia Group.

10. Kementrian Kesehatan RI (2015) 'Peraturan Menteri Kesehatan Republik Indonesia Nomor 97 Tahun 2015 Tentang Peta Jalan Sistem Informasi Kesehatan Tahun 2015-2019'.

11. Mardiyanti (2018). Pengaruh Pengetahuan, Motivasi, Imbalan, Kepemimpinan, Dan Beban Kerja Terhadap Kinerja Bidan Puskesmas Dalam Penyeliaan Fasilitatif Program Kesehatan Ibu dan Anak di Kabupaten Lumajang. Tesis Repository Universitas Jember.

12. Susanto, Azhar (2002). Sistem Informasi Manajemen. Bandung : Linggar Jaya

13. Sari, Intan Risan, dkk (2016). Sistem Informasi Pencatatan dan Pelaporan Puskesmas Program Kesehatan Ibu dan Anak Pada Dinas Kesehatan Kabupaten Kudus. Jurnal SIMETRIS, vol 7 No 1 April 2016.

14. Kementrian Kesehatan Republik Indonesia (2016). Peraturan Menteri Kesehatan RI No 44 Tahun 2016 Tentang Pedoman Manajemen Puskesmas.

15. Kementrian Kesehatan Republik Indonesia (2019). Peraturan Menteri Kesehatan RI No 43 Tahun 2019 Tentang Pusat Kesehatan Masyarakat.

16. Pangarso, Astadi (2016). Perilaku Organisasi. Yogyakarta: Deepublish 